\title{
Microfinance, Non-Ideal Theory, and Global Distributive Justice ${ }^{1}$
}

\section{Daniel Butt}

\section{Introduction: Political Theory and Microfinance Scepticism}

There are many reasons why political theorists might be suspicious of real world microfinance institutions. First, and most importantly, there is currently considerable uncertainty about the effects of microfinance initiatives in practice. As has been well documented, controversy has recently grown as to the efficacy of such institutions in the fight against global poverty. Concerns have also ben expressed about the the effects of schemes on participants, the recent spate of suicides in India apparently linked to the pressures of repaying microcredit debts and widespread subsequent defaulting (BBC News 2010; Polgreen and Bajaj 2010; Solan 2011).

Even if one believes that allowing the microfinance market to respond to the need of some of those excluded from conventional financial services assists poverty alleviation, one might still worry that this net benefit comes at the expense of particular individuals who suffer disproportionately from, for example, their inability to repay the interest on their microcredit loans. Such a phenomenon is likely to be troubling to theorists who reject the utilitarianism sometimes used in market-centred macroeconomic policy making in favour of an approach which affirms the "separateness of persons" and is troubled if the interests of the many seem to be advanced at the expense of the few (Rawls 1972: 26-7). For some, the claims made by the advocates of microfinance are simply too good to be true. As Jonathan

\footnotetext{
${ }^{1}$ I am grateful to members of the AHRC Microfinance Network project, and particularly Luis Cabrera and Tom Sorrell, for their help in writing this article.
} 
Morduch noted in urging caution as to "the promise of microfinance" in 1999, "Alleviating poverty through banking is an old idea with a chequered past" (1999: 1570).

It is now commonplace to accept that microfinance can impose significant costs on its participants, beyond the extremely high levels of interest which some microcredit schemes charge. As Johnson and Rogaly write, "Financial relationships, especially those of debt, are one way in which the powerlessness of groups of poor people is entrenched (1997: 119). Others worry that the emphasis on non-intervention with market workings has been co-opted by those with a right wing, neo-liberal agenda, and in fact serves the ends of excusing developed states from fulfilling their duties of distributive justice to the world's poor.

All of these are weighty and significant concerns, and they obviously raise important questions about the institutional design and practical effects of microfinance in general, and of particular microfinance programmes. It does seem clear, though, that microfinance initiatives have had at least some success in affording a range of financial services, including insurance, provision for savings, and credit, to individuals who were previously unable to transact with the mainstream financial services industry, and so were dependent on less formal financial service providers such as moneylenders, who characteristically conduct business on much less advantageous terms.

Such practical concerns, however, do not exhaust the set of worries that political theorists might have about microfinance as a response to poverty and social exclusion. One particular source of disquiet can be traced to the role of non-governmental actors in the provision of microfinancial services. Principle 8 of the CGAP" "Good Practice Guidelines for the Funders of Microfinance", as adopted by the members of the G8, holds that, "The job of government is to enable financial services, not to provide them directly. Governments can

\footnotetext{
${ }^{2}$ Consultative Group to Assist the Poor.
} 
almost never do a good job of lending, but they can set a supporting policy environment" (CGAP 2006).

Microfinance aims to work though the agency of non-governmental actors, be they not-for-profit organisations or private corporations. The promise of the microfinance movement is that significant numbers of people can be lifted out of poverty without the need for intervention or redistribution by the state. The temptation, then, is to see microfinance as serving the ends of justice. There is substantial debate amongst political theorists as to the nature of global distributive justice, understood as the fair distribution of benefits and burdens between states and peoples. Some advocate cosmopolitan principles, which do not attach ethical significance to national identity; others stress the significance of national selfdetermination and argue that fairness requires holding states responsible for their choices. But there is a near consensus that either justice or morality requires urgent action to alleviate the pressing problem of world poverty. So, writers who oppose highly redistributive principles of global egalitarianism nonetheless are typically willing to endorse some variant of sufficientarianism: the idea that there is a general duty to seek to ensure that everyone has access to the resources and opportunities necessary for a minimally decent life (see Casal, 2007). A range of different theories, then, can agree that urgent action is both justifiable and needed to remedy the situation of the world's poorest.

Microfinance might seem to be able to assist in bringing about this end. The advocates of microfinance do not claim that it is a panacea, and they stress in particular that it is unlikely to be beneficial to the very poorest people in the world, who are likely to need direct aid if they are to be assisted. But in seeking to improve the position of large numbers of people currently below the sufficientarian threshold, it appears that microfinance has the potential to make a valuable contribution to the pursuit of global distributive justice, at least making the world a more just place than it would otherwise be in terms of the international 
distribution of benefits and burdens. So, why should microfinance for this purpose be problematic?

In fact, much left-leaning political theory has traditionally either assumed or explicitly argued for a prominent role for the state. Historically, questions of distributive justice were typically framed for a territorially bounded state, possessing a government with a monopoly on the legitimate use of coercive force, ultimately able to make or unmake any law, and so possessing the right to alter the allocation of property within its borders, taking property from some, and re-assigning it to others. If such a state is viewed as an agent of justice, through which, in a democracy, the people are both able and required to act, it is natural to see the state as the primary organ through which distributive justice is to be realised. As Robert Goodin writes, "The state has a duty to organize - and the power to enforce, as necessary various sorts of co-ordination schemes to aid its citizens in discharging their individual (albeit imperfect) moral duties" (Goodin 1989: 137). If some individuals have too many resources, and others too few, the state should intervene, utilising the threat of coercive force to move resources from the former to the latter.

There is a temptation here to think of distributive justice as a zero sum game in which one individual's loss is another's gain, but this need not be true in practice. Changes to the allocation of property do not simply have the effect of moving around entitlements from one person to another; they also affect the productive choices that people subsequently make. A determination of principles of distributive justice does not just tell us how we should share out a pie - the choice of principles makes a difference to the size of the pie itself. John Rawls's "Difference Principle" which permits departures from equality when such departures are necessary to improve the position of the least advantaged productive class in society, is concerned with just such a phenomenon, insofar as it seeks to give individuals incentives to increase their production (Rawls 1972: for discussion, see Cohen 2008). 
The key to the microfinance approach to poverty alleviation is economic growth. Rather than seeking to redistribute resources from the haves to the have-nots, the core key idea is that linking have-nots together by means of low level financial institutions can allow a more efficient use of resources: in facilitating both saving and borrowing, enabling security and protecting against shocks, money is freed up to enable individuals and families to make longer term financial decisions and both save for and invest in their futures. Whether or not such an approach is problematic depends on one's perspective on the justice of current international resource distributions. Suppose that one accepts that current resource holdings are not ideal, and that there are policy decisions which could be taken which would improve matters from the perspective of distributive justice. What is wrong with contemporary holdings? Is the problem that some do not have enough? Or is it also a problem that some have access to what others should have?

Insofar as microfinance does not prescribe redistribution from the haves to the havenots, but instead advocates helping the have-nots to become haves, it leaves the resource holdings of affluent individuals and states untouched. For some, this is not a problem so long as action is being taken to ensure that all have an adequate standard of living. For others, this meeting of a sufficientarian threshold would not be sufficient for the realisation of distributive justice - further redistribution would be necessary. Indeed, from the perspective of the advocate of redistribution, profit-making microfinance initiatives may actually make distributions more rather than less unjust, their purported beneficial effects on their clients notwithstanding. ${ }^{3}$ So the first question to be answered concerns the nature of background

\footnotetext{
${ }^{3}$ The idea here is that the rise in the position of the poor might be more than offset by the rise in inequality caused by the profit accruing to the MFI. The point can be seen by thinking of the example of conventional moneylenders, who charge what often appear to be exorbitant interest rates. Some may argue, of course, that such agents harm the poor, and so straightforwardly fail to serve the ends of justice. But even if the poor do end up better off as a result of their involvement with the moneylender, the degree of profit taken by the moneylender may have a net negative effect on the overall justice of the distribution. Consider the following, highly simplified distribution, of an inegalitarian world with three agents. A has 1 unit of resources, B has 4, and $\mathrm{C}$ has 13. $\mathrm{C}$ lends five units to B. B uses these units to produce a further three units. $\mathrm{C}$ reclaims the five units of
} 
accounts of international distributive justice. Suppose we accept that at least certain microfinance initiatives have the effect of raising large numbers of their clients from below to above a point which marks a minimally decent level of flourishing. To what extent does this serve the ends of distributive justice?

\section{Characterising the Injustice of Contemporary International Resource Holdings}

It may be thought that the distinction developed above between poverty alleviation through redistribution and poverty alleviation through growth maps rather well onto contemporary debates about global distributive justice. In particular, the distinction seems to mirror Charles Beitz's well-known distinction between cosmopolitan liberalism and social liberalism. Beitz draws on contemporary work in political theory to outline two broad schools of thought on international distributive justice, both of which move beyond the realpolitik of prescriptive realism in accepting that states possess at least some moral duties to others. Both are concerned with fairness in international relations, but they conceive of the basic units of international society in different ways: "Social liberalism holds that the problem of international justice is fundamentally one of fairness to societies (or peoples), whereas cosmopolitan liberalism holds that it is fairness to persons" (1999: 515). Social liberalism draws upon a conception of the international realm as an order of societies organized as states:

There is a division of moral labour between the domestic and international levels. State-level societies have the primary responsibility for the well-being of their own people, while the international community serves to establish and maintain background conditions in which just domestic societies can develop and flourish. The agents of international justice are states or societies, and its object is to establish a political equality of states, each committed to and capable of satisfying the legitimate interests of its own people (518).

the loan, and takes two of the three new units as an interest payment. We have thus moved from D 1 (A: 1, B: 4, $\mathrm{C}: 13$ ) to D2 (A:1, B:5, C:15). From an egalitarian perspective, D2 looks prima facie to be more unjust than D1, the improved position of B notwithstanding - certainly, the inequality between each of the agents, and the overall inequality of the distribution, seems to have increased. For relevant discussion, see Temkin 1996. 
Rawls is one of the most obvious advocates of such a position (1999). This broad approach, however, can be seen as consistent with the work of a range of writers who stress the significance of nationality (Tamir 1993; Miller 1995; 2007), the coercive aspect of state law (Blake 2002), joint authorship of coercive law (Nagel 2005), fair reciprocity (Sangiovanni 2007), or other putatively relevant differences between state members and non-members, in order to argue that what is owed, as a matter of distributive justice, to fellow members of one's own political community is different to that which is owed to non-members. By contrast, cosmopolitan liberalism denies the ethical significance of national identity or national membership in relation to distributive justice:

In contrast to social liberalism, cosmopolitan liberalism accords no ethical privilege to state-level societies. It aims to identify principles that are acceptable when each person's prospects, rather than the prospects of each society or people, are taken fairly into account... cosmopolitan liberalism effectively extends to the world the criteria of distributive justice that apply within a single society (Beitz 1999).

Advocates of cosmopolitan liberalism include Beitz himself (1979; 1983), Thomas Pogge (1995), Onora O’Neill (2000), Darrel Moellendorf (2002), and Simon Caney (2005). One way to articulate the difference between the positions, then, might be to say that cosmopolitan liberals are concerned with relative levels of well-being of those in other political communities, and social liberals with absolute levels. If cosmopolitan liberals advocate redistributive principles of justice in the domestic sphere, it follows that they believe that justice requires similar redistribution internationally. By contrast, insofar as social liberals believe that there are positive distributive duties to those in other countries, as opposed to negative duties of non-intervention and respect for sovereignty, these are characteristically portrayed as limited to what is needed to bring individuals up to a sufficientarian threshold. Social liberals do generally accept that there are duties to help those in need in other countries, but these are duties are limited to ensuring some minimal degree of flourishing. 
Thus Rawls, for example, speaks of a limited duty of assistance to those in need with a "cut-off point," but against "a global egalitarian principle without target", claiming that "Surely there is a point at which a people's basic needs (estimated in primary goods) are fulfilled and a people can stand on its own" (1999: 119). Once this cut-off point is reached, and a people is able to look after itself, he sees no further need for redistribution - henceforth, the political culture of the people is the critical factor in its development.

In The Law of Peoples, Rawls describes two imaginary societies. Each begins from the same starting point, but they choose to adopt different policies: one deciding to industrialize and increase its rate of saving, the other preferring a more pastoral and leisurely society. Suppose that, decades later, the first country is twice as wealthy as the second. Rawls asks:

Assuming, as we do, that both societies are liberal or decent, and their people free and responsible, and able to make their own decisions, should the industrializing country be taxed to give funds to the second? According to the duty of assistance there would be no tax, and that seems right; whereas with a global egalitarian principle without target, there would always be a flow of taxes as long as the wealth of one people was less than that of the other. This seems unacceptable. (Rawls 1999: 197)

It might appear, then, that microfinance is a good fit for social liberalism. Insofar as social liberals are interested in redistribution on account of its capacity to fulfil duties of assistance, microfinance holds out the hope of being able to assist at least some of those in need without necessarily requiring a direct transfer from rich to poor. Instead, the micro provision of financial services allows flourishing sufficient to reach the sufficientarian threshold. So the question of whether microfinance can serve the ends of justice would hinge on whether one's background account of distributive justice was better characterized as social liberal or cosmopolitan liberal. Cosmopolitan liberals, or, at least, those cosmopolitan liberals who advocate some version of global egalitarianism, have good reason to seek substantive redistribution so as to lessen or remove inequalities between persons, but if one holds that 
social liberals' duties to non-nationals are limited to non-intervention and ensuring a minimally decent quality of life, it does not seem that the actual redistribution of resources is necessary if the sufficientarian goal can be reached by other means.

This view of the easy reconcilability of social liberalism and microfinance is deeply misleading, however. The problem is that it overlooks the need for extensive redistribution on even the social liberal account. Social liberalism gives an account of how a just world could feature inequality between nations if duties of assistance were fulfilled, but there is no reason to think real world has come about in this way. Thomas Nagel has written, "We do not live in a just world. This may be the least controversial claim one could make in political theory" (2005: 113). Crucially, this is true from even the social liberal perspective - the world is deeply, profoundly, tragically, grotesquely unjust. It is easy to miss this point when reading ideal theory examples such as that of Rawls above, whereby we imagine peoples starting from equal starting points, interacting justly with one another and reaching different end points. But there is no reason to think that this bears any relation to actual international history or to contemporary international relations, both of which can instead be characterised in terms of persistent, grievous, ongoing injustice.

There are many ways to make this point. Some are more contentious than others. Thomas Pogge's recent work, for example, has avoided the controversial egalitarian cosmopolitanism of his earlier writing, instead arguing that the structure of international society means that those living in more developed states are responsible for causing harm and infringing the negative rights of persons living in the contemporary developing world. He claims that those who live in poverty "are being harmed through a badly slanted global order in whose continuous shaping and coercive imposition we are materially involved" (2002: 133). Thus, "severe poverty is an ongoing harm we inflict upon the global poor $(2005: 1$, for discussion, see Patten 2005). My own work has argued that the adoption of social liberalism 
commits one to a backward looking account of distributive justice, which in turn gives rise to potentially massive claims for compensation and restitution as a result of historic wrongdoing (Butt, 2009a). Ypi, Goodin and Barry have looked to the developed world's colonial past to suggest that peoples who now live in other states may be entitled to compensation as a result of a historic failure to fulfil distributive duties to their ancestors (2009; see also Butt, 2009a: 115-17).

Even if one does not wish to endorse any of these claims, there is a more straightforward route to the conclusion of massive contemporary injustice, which stems from the observation that duties of assistance are not currently being met, with the result that hundreds of millions of people suffer serious preventable harms. These individuals, who are denied essential healthcare, who suffer from hunger and malnutrition, who witness the preventable deaths of loved family members as a result of a failure on the part of the developed world to act to develop institutions to fulfil their collective responsibilities, are the grievously wronged victims of contemporary international injustice. These harms themselves give rise to rectificatory duties: the failure to fulfil duties of assistance alone is a serious act of moral wrongdoing, which stands in need of (at least) rectificatory redistribution. There would still be a serious moral case to be answered even if the world dramatically changed and all of the developed states' duties of assistance were met overnight, given that in the period leading up to the present they have not been fulfilled. This argument is dependent upon the idea that it is feasible and not overly demanding for the developed world to do more (and to have done more in the past) to fulfil these duties. Though this point needs to be argued, there is convincing empirical evidence to support it (Pogge 2002:196-225).

The real world context, then, is one where pressing distributive duties are currently not being met. What exactly is owed is obviously a deeply contentious question, which will largely depend upon one's background account of distributive justice. For example, quite 
what a cosmopolitan egalitarian distribution of resources would look like is very much contested within egalitarian theories. One very simplistic account would simply take global GDP, divide it by the number of people in world, and give each an equal share. ${ }^{4}$ Such an approach is in some ways far too crude - if we were really were seeking such a metric, we might want to take purchasing power parity into account; to think about the value of natural resources, whether currently exploited or unexploited, by different communities; to consider geographical, cultural, and linguistic sources of advantage, and so on. But it is clear that such an egalitarian distribution would raise the world's poor considerably above both the $\$ 1$ and $\$ 2$ a day poverty lines, would be more than enough to raise all individuals past any plausible minimal sufficientarian threshold, and would dwarf the value of the benefits which individuals characteristically receive from microfinancial institutions.

It should be made clear that this claim does not turn upon the question of whether such equal shares are paid out in straightforward cash terms. There is no particular reason why global distributive justice could only be served by parcelling up the world into discrete bundles of private property rights. We may well hold that affording individuals more limited rights and retaining at least a degree of collective holdings, at the local, national or international level, constitutes a better model, for a range of possible reasons -- overall efficiency, fairness, outcome of democratic decision-making, and so on. So it would be possible, under an egalitarian scheme, to afford individuals the same sort of rights over property that they gain through microfinance initiatives. It does seem, however, that the value of such a package, combined with the value of public goods provided by collective means, would have to be at least similar to that which would be afforded to individuals if there were simply a straightforward division of resources - and it does seem as if most existing

\footnotetext{
${ }^{4}$ According to the World Bank, global GDP per capita in 2012 was $\$ 10,351.7$. See "GDP per capita (current US\$)", at World DataBank: World Development Indicators, available at http://databank.worldbank.org/data/ [last accessed 21/11/2014]
} 
microfinance initiatives and public goods schemes in the developing world do not benefit their participants to this very substantial extent.

The question of what redistribution should be favoured by social liberals is, if anything, more complicated, especially if we believe that rectificatory payments should be paid not only for historic or contemporary negative rights violations, but also for a contemporary failure to fulfil duties of assistance. ${ }^{5}$ There are good reasons, however, to think that the amounts are likely to be significant. It is striking that, when Robert Nozick confronted a similar issue facing the principle of rectification in his theory of historical entitlement, he was prepared to countenance a one-off redistribution of all resources in society in accordance with Rawls's Difference Principle (Nozick, 1974: 221). Clearly a full account of the redistributive implications of social liberalism needs much more argumentation, but it should be clear that a plausible case can be made for the fact that even social liberals should accept the existence of extensive unfulfilled distributive duties to many of the world's poorest peoples.

\section{Microfinance and Non-Ideal Theory}

Suppose we accept the argument of the preceding section. The conclusion is that the current international distributive order is seriously unjust, and that there are multiple agents failing to fulfil their distributive duties to others. It is true that their failure so to act means that many individuals are below a minimal threshold of decent provision, and also perhaps true that this consequence of individuals being preventably below a sufficientarian threshold means that their failure to act justly is particularly egregious. Yet, the fact that their failure to act means

\footnotetext{
${ }^{5}$ There is remarkably little scholarly literature available on this latter question, of the extent to which a failure to fulfil distributive duties gives rise to rectificatory duties. It might be noted nonetheless that a failure to comply with, for example, egalitarian principles of distributive justice in relation to persons who are above the sufficientarian threshold might be different in nature, and less morally problematic, from a failure straightforwardly to comply with duties of assistance to raise individuals to decent minimum levels of wellbeing.
} 
that persons are below this threshold is not constitutive of their wrongdoing - redistribution would be required even if these wronged persons were to be brought up to the threshold by other means, such as a windfall gain of manna from heaven. This failure to fulfil the requirements of justice is systematic, reflected in the provisions of existing international institutions and the character of contemporary international law (Pogge 1992; Butt 2009b) and on-going. It also seems fair to say that it is predictable that distributive injustice will continue to be the norm. Even if one were to believe that there have been some positive signs on the international distributive front in recent years, there are at least as many negative indicators, relating to, for example, increasing global inequality, slow action on climate change, and the recent lack of progress towards the Millennium Development Goals.

All of this matters for a consideration of the ethics of microfinance. It means that such a consideration takes place squarely within the realm of non-ideal theory, against a backdrop of a lack of compliance with moral duties. Microfinance institutions target those individuals who are excluded by mainstream financial institutions, on account of their relative lack of affluence. As argued above, there are good reasons to think that such individuals would be in a much better position in a world where global distributive justice was realised. In broad terms, it seems fair to say that they would certainly have less pressing need of microfinancial provision, and indeed, in many cases, would not need microfinancial services at all, since their increased level of affluence would make them more attractive to conventional suppliers of financial services, and may well at least lessen the urgency of their need for credit, if not for savings facilities.

If we focus on microcredit specifically, the point becomes starkly clear. Microcredit initiatives in a non-ideal world involve lending money to people, at demanding rates of interest, to make up for a lack of advantage which has been wrongfully withheld. There is good reason, then, to think that many of the people who currently do or could benefit from 
microfinance would not need to do so in a just world. Participants in microfinance schemes are being afforded limited rights over resources which should be theirs by right. A world with widespread access to microfinance may be better than the current world without such access, but both are worse than a just world where each individual has their fair share of the world's property.

The ideal-theory response to the current non-ideal state of the world, then, would be a redistribution of resources which would obviate much or all of the need for microfinance in its current form. A world with microfinance is less just than such a world, even if microfinancial initiatives are successful in lifting people out of poverty above the sufficientarian threshold. But the fact that microfinance would not feature in an ideally just society does not mean that microfinance is unjust, any more than the fact that Robin Hood would not have needed to steal from the rich to give to the poor in a just society meant that Robin Hood was unjust. If, as above, we take it as a given that international redistribution is not likely to take place in (at least) the near future, should we not see microfinance as part of the next best solution to global poverty, which asks what the best available response is in the predictable absence of a fulfilment of distributive duties.

There are a number of possible responses to such a claim. One obvious response is to look into the practical effects of microfinance, and ask whether it really is beneficial for those who participate. If microfinance causes or risks harms to individuals on a serious scale, the claim that it is the next best policy in the absence of full compliance is obviously open to question. Relatedly, one might ask whether it is really not feasible to persuade or pressurise the governments of developed states to fulfil at least some of their distributive obligations to those in need. So one might worry, for example, that microfinance initiatives effectively let such bodies off the hook. Rather than feeling obliged to step in and seek to relieve poverty directly, they are now able to point to local microfinance initiatives and maintain that their 
assistance is not necessary. So while microfinance may seem beneficial, it crowds out alternative approaches which are not put into practice.

Such disputes are familiar in the existing literature on microfinance. An alternative set of questions concern not simply the practical effects but the ethics of microfinance, and of microcredit initiatives in particular. Microcredit involves lending money to individuals with a pressing need for resources, at interest rates which are typically much higher than those charged by regular financial institutions. How should we judge the justifiability of such practices? What constitutes a fair rate of interest on a loan? Can a loan be consensual and yet be said to infringe the rights of one of the parties to the loan?

The obvious way to approach such questions is by an application of the existing literature on exploitation. ${ }^{6}$ There is much controversy amongst political theorists as to what forms of interaction between persons constitute exploitation, but it is possible to identify a generally shared core to the concept in the idea that to exploit someone is, in some sense, to take unfair advantage of them (Goodin 1987: 166; Wertheimer 1996: 16; Logar 2010: 333). Such questions of exploitation can arise both in contexts of background distributive justice and of background distributive injustice. Imagine that we endorse a particular theory of distributive justice -for example, luck egalitarianism-- that permissibly gives rise, in ideal contexts, to distributive inequalities between persons. Luck egalitarians hold that inequalities can be just if and only if they emerge from choices for which it is reasonable to hold persons responsible (for an overview, see Lippert-Rasmussen, 2009).

Imagine a just luck egalitarian society, where each individual started from an equal starting point, adjusted to allow for disparities in natural endowments, and subsequently chose to expose themselves to option luck to varying degrees, resulting in some individuals having significantly more resources than others. Such a distribution would be just. Suppose,

\footnotetext{
${ }^{6}$ See also Sherratt and Sandberg chapters, this volume.
} 
then, that the poorer individuals found themselves in a disadvantaged position, whereby they were excluded from conventional financial services on account of their poverty - and so sought to borrow money from the more affluent. A series of ethical questions would arise as to what credit terms would constitute exploitation of the poor. Different theoretical accounts of exploitation answer this question in different ways. Some accounts focus primarily on the voluntariness or involuntariness of the transaction (Steiner 1987; Moore 1973 (quoted in Wertheimer 2008)); others seek to analyse the relative bargaining positions of the different parties and assess whether the agreement departs unfairly from benchmark equilibrium process (Miller 1987).

Of particular interest for the assessment of microcredit schemes is Robert Goodin's account, which holds that the unfairness associated with interpersonal exploitation lies "in playing for advantage in situations where it is inappropriate to do so" (Goodin 1987: 184), in a way which violates the moral norm of protecting the vulnerable (187; see also Goodin 1985). He identifies four principal ways in which this happens in modern societies: it is thought wrong to play for advantage against others who have renounced playing for advantage themselves; against others who are unfit or otherwise unable to themselves play; against others who are no match for you in games of advantage, and when your relative advantage derives from another's grave misfortune (185-6). Such an account can clearly be applied to the microfinance situation - we look to the power differentials between the different parties, which given the poverty of many microfinancial clients can be great, and ask whether the agreement violates duties to those who are vulnerable on account of their level of well-being.

Ruth Sample, developing Goodin's approach, is explicit that it is the absolute level of well-being which is at issue in determining whether a given transaction is exploitative, and particularly whether any party's basic needs are at issue: 
I reject the idea that a person could be exploited if no vulnerability is made use of. A person whose basic needs are met, and who nonetheless chooses to transact in a way that would violate a putative restriction on exchange, is not exploited (Sample, 2003: 83, cited in Logar, 2010: 340).

It might be thought that this form of approach lends itself well to the question of whether microfinance is exploitative. However, there is a significant difference between the hypothetical luck egalitarian context and the real world, in terms of how the different parties came to their present positions of advantage and disadvantage. The ethics of lending money to those who are responsible for their lack of resources is not the same as the ethics of lending money to the victims of injustice. The background context of distributive injustice makes a significant difference to the ethics of microcredit, and to judgments we make about the exploitative character, or otherwise, of the enterprise. It matters that those who are being loaned money at high rates are not just the disadvantaged, but people who are disadvantaged as a result of the unjust actions of others. This, it will be argued, is particularly the case when those involved in the provision of credit are seeking to gain advantages from the scheme in question.

This is not quite the same as the question of whether the institutions in question are for-profit or not-for-profit, since it is clear that there many ways in which the employees of not-for-profits can benefit from their employment. To take an obvious example, private schools in the United Kingdom, which typically pay higher salaries to their employees than those available in the state sector, are registered charities, with a formal non-profit making status. But for-profit microfinancial institutions are the most obvious examples of those who seek to benefit from the provision of microfinancial services. My claim in this section is that such actions are wrongfully exploitative, regardless of the interest rate which they charge, on account of the fact that the institutions in question are seeking to take advantage of the victims of injustice. It is this sense in which for-profit institutions are profiteering at the expense of people who should have more than they do, rather than just exploiting the poor in 
a more straightforward sense, which I believe explains much of our intuitive unease at the idea of profit-making microfinancial initiatives.

This approach is certainly controversial, as it involves the contentious characterization of a form of exploitation. The account of exploitation has a similar structure to, but is distinct from, that articulated by Robert Goodin. As stated above, Goodin's claim is that at the heart of a claim that one person is exploiting another is the idea that the former is taking advantage of the latter: "The generic unfairness associated with interpersonal exploitation lies... in playing for advantage in situations where it is inappropriate to do so. "(184) My claim is that it is inappropriate for moral agents to seek to gain advantage from the perpetration of injustice, and that this constitutes an instance of taking unfair advantage of the victims of injustice. My account does not depend upon the victims of injustice necessarily having suffered "grave misfortunes" or being below some minimal threshold of well-being, (though clearly, it may be that both elements are also present in practice). As such, unlike Goodin's, it does not necessarily involve the infringement of a duty to protect the interests of those who are particularly vulnerable to our actions and choices. Instead my claim relates to a separate moral norm, which holds that moral agents have a general duty to uphold and not to undermine justice through their actions.

The structure of this argument is similar to that which I and others have made elsewhere in relation to the general question of whether individuals can come to have rectificatory duties as a result of benefiting from injustice for which they were not themselves responsible (Butt 2007; Gosseries 2004). Such accounts are controversial, since they hold that such duties can be acquired through the involuntary receipt of benefits (Fullinwider 2002, Anwander 2005). But in this case, there is no obvious involuntariness - in for-profit microfinance individuals and institutions actively seek to benefit from the scarcity of resources which results from the absence of global distributive justice. My claim is that this 
unjust distributive backdrop means that standard accounts of exploitation do not adequately capture the unethical aspect of for-profit microfinance providers. The problem is not just that they are exploiting the poor; they are exploiting the wronged. Such an exploitation contradicts and undermines their status as moral agents by violating their duty to uphold justice.

To illustrate this point, consider first the case of wealthy individuals who possess unfulfilled distributive duties to the poor. Suppose that we accept that the world would be more just if some of their resources were transferred to the disadvantaged, including those who are recipients of microcredit. Were there an institution with the relevant authority and resources, it would act justly in using coercive force to tax such individuals in order to bring about such a resource redistribution. If such an institution existed, the rich would possess a moral duty to comply with its requirements, and not to seek to evade paying their fair share of tax. The question of what precise obligations such individuals have in a context where such institutions do not exist and there is a general lack of compliance with distributive duties is a difficult and contested one (Cohen 2000; Murphy 2000). We need not (though we may) hold that they act wrongly in not voluntarily transferring resources to the disadvantaged. Many believe that this is too demanding in a general context of non-compliance, and that a failure to redistribute their resources is justifiable (or perhaps, to use a less strong term), excusable. But this does not let such individuals off the moral hook, in the sense that the moral slate is wiped clean, and it is justifiable for them to act in the same way that they could justifiably act against a background of distributive justice. In particular, there are certain actions which would be justifiable against such a background and which are not in a non-rectified context. Certain forms of interaction with the disadvantaged fall into this category. It is one thing to claim that it is too demanding to transfer one's resources to the disadvantaged. It is quite another then to take advantage of the differential levels of advantage which this refusal 
creates to make a profit from them. The latter case is, in the microcredit example, effectively charging people interest for lending them their own money.

The argument can be taken further, to apply not only to the case where those with unfulfilled distributive duties launch microfinance initiatives, but more broadly, to any context where an agent or agents seek to extract a direct benefit from the unjust disadvantage of others. ${ }^{7}$ A situation where individuals are paying interest to borrow money which they should have as a matter of right is unjust. The primary or initial responsibility for this injustice lies straightforwardly with the agents who are failing to fulfil their distributive obligations. It is true that the clients of microcredit scheme are wronged because of their level of resource holdings, and true that it is wrong that they have to pay interest to obtain access to resources which they ought to have as a matter of right, but this does not necessarily mean that microfinancial institutions are guilty of or even complicit in injustice insofar as they are not seeking to take advantage of these victims.

As soon as institutions seek to gain benefits from the situation of these individuals by extracting a surplus, however, they are guilty of wrongdoing. Strikingly, this is true even if the credit if offered on terms which we would not deem as exploitative if they took place against a backdrop of distributive justice. Equally strikingly, two microfinance institutions might offer identical terms to the same individuals, one of which counts as wrongfully exploitative, and one of which does not on account of the former's seeking to gain advantage from injustice. The conclusion of this section, then, is that it is not sufficient to defend microfinancial institutions to construct an account of what would count as exploitation in a

\footnotetext{
${ }^{7}$ It may be argued that in a situation of gross background injustice, it is almost impossible not to, in a sense, benefit from the wrongdoing of others. Any consensual market transaction which involves resources which would belong to others in a just society may be said to have such a character, as a result of what Jeremy Waldron has called the "contagion of injustice" (Waldron 1992: 11). This account therefore seeks to differentiate between a deliberate attempt to extract direct benefit from the unjust disadvantage of another, and forms of interaction where benefit is acquired, but the connection with injustice is indirect. It may still be the case that individuals possess rectificatory obligations in contexts where they receive indirect and/or involuntary benefits form injustice (see Butt 2009a: 129-30).
} 
Microfinance, Rights and Global Justice

situation of background distributive justice, and then measure real world institutions against this index. The fact of non-ideal real world injustice complicates, at the very least, the ethics of the provision of microfinance.

\section{Microfinance, Ethics and Public Policy}

This article has made two principal claims. The first is that the extent of unrectified distributive injustice in the world means that microfinance initiatives should be seen as part of a non-ideal, (at best) second-best response to global poverty. The second is that this unjust distributive backdrop means that those who seek to gain advantage from the victims of injustice by seeking to extract a surplus from microfinance initiatives wrongfully exploit their clients. The practical implications of these claims, however, are not clear, and this is again a consequence of locating microfinance within the realm of the non-ideal. A determination that microfinance is not ideally just tells us that the world would be a better place if action were taken which made microfinance initiatives unnecessary.

This does not mean that in the predictable absence of such action, it is wrong to pursue poverty alleviation by means of microfinance, particularly insofar as the agents pursuing microfinance based solutions are not the agents responsible for the failure to pursue the ideal course of action. Even a determination that surplus-extracting microfinance wrongs its victims does not lead to the conclusion that it would be better if these initiatives did not exist. The fact that something is unjust does not necessarily mean that it is better if it does not take place. Sometimes it may seem as if this is the case in the realm of ideal theory - John Rawls famously argued that "Justice is the first virtue of social institutions, as truth is of systems of thought" (1972: 3). However we choose to conceive of justice in ideal theory, once non-compliance with moral obligations enters the picture, things become decidedly murkier. There are many contexts where it is commonly believed that it can be justifiable to 
trade off the acknowledged value of justice for other sources of ethical value: peace; wellbeing; human flourishing; and so forth.

Such difficult trade-offs emerge frequently, for example, in both criminal and transitional justice contexts. In his posthumously-published essay "How to Do Political Philosophy," G.A. Cohen distinguishes between three distinct questions in political philosophy which, he writes, "are not distinguished as often as they should be, to the detriment of both clarity of statement and rigor of argument within our discipline" (2011: 227). These distinct questions are:

i) What is justice?

ii) What should the state do?

iii) Which social state of affairs should be brought about?

(i) and (ii) are distinct since not everything the state should do is a matter of justice, and since not all justice is to be achieved by the state. Similarly (ii) and (iii) are distinct, since social states of affairs can be brought about by agents other than the state, the state's monopoly on legitimate coercive force notwithstanding. Finally, question (iii) is different from question (i) since "justice is not the only reason why it might be right to bring about this social state of affairs rather than that one. Social states of affairs can have, and lack, virtues other than that of justice" (2011: 217).

Such distinctions have obvious relevance for the question of what is to be done in relation to real world microfinance initiatives. This article has been principally concerned with the first of these questions, assessing the justice and injustice of real world microfinance programmes. But a judgement that microfinance programmes are not ideally just, and even a conclusion that particular programmes wrongfully exploit their clients, does not necessarily tell us what either state or non-state actors - including the institutions themselves - should do in an all-things-considered sense. Robert Goodin makes this point in the context of his 
discussion of the nature of exploitation, writing: "an act of exploiting a person always constitutes a wrong. To say that such an act necessarily constitutes $a$ wrong is not, however, to say that it is necessarily wrong on balance to perform it." (1987: 173).

Insofar as it is true that microfinance benefits individuals in need, raising their level of prosperity, making them less susceptible to various harmful outcomes and increasing their opportunities, it obviously has ethical value. So from the perspective of the state, for example, the fact that profit-making microfinance wrongly exploits the victims of injustice is not necessarily sufficient reason to intervene and prohibit the practice in question. It does provide $a$ reason, but this must be balanced against the predictable costs that such actions would also produce. This type of balancing of different sources of ethical value is not unusual, and comes to the fore in a certain category of cases of exploitation, where parties to a contract both consensually and voluntarily enter into the contract, and benefit from the contract, in the sense that they are better off having made the contract than they most likely would have been in the absence of the contract (for discussion, see Butt, 2012: 237).

This may well be the case in relation to many microfinance agreements. Delicate judgment is required here, since the exploitative nature of the contract is not sufficient to require the state to intervene to void the agreement, and nor is the mutual benefit sufficient to prohibit the state from so intervening. Easy extreme cases can be constructed on either side, and the difficult cases, inevitably, are somewhere in between. A judgment of injustice contributes, we might say, at least a thumb on the scales to this balancing of ethical value. How much regard should be paid to justice obviously depends on the degree of injustice involved, but also on the importance of the interests which the exploitative act advances.

Of course, it need not be maintained that states face stark binary choices of whether to permit or prohibit practices. They are agents in their own right, and so may well be able both to prohibit certain forms of interaction and to act themselves in such a way as to mitigate the 
damaging effects of the prohibition on the interests on the participants: by regulating microfinancial institutions in a different way, such as capping permissible interest rates; by providing subsidies to not-for-profit competitors; even by setting up their own not-for-profit microfinance scheme, for example. What does seem clear is that states in some situations will need to countenance (in the sense of refusing to prohibit) forms of interaction which treat some of their citizens unjustly, if the alternative is likely to be worse for their basic interests. It should be clear that this does not amount to a crude consequentialist claim that the state should always act in such a way as to increase the welfare of its citizens. The state is indeed an agent of justice, with, at the very least, a prima facie duty to uphold and promote the pursuit of justice. But most would deny that they have an absolute duty to uphold the Roman legal maxim "fiat justitia ruat caelum" (let justice be done though the heavens fall).

The judgment that taking advantage of the victims of injustice wrongs these victims does not even lead to the conclusion that microfinance institutions should refrain from acting in such a way. Obviously, it would be better if they instead benefited the victims of injustice without wronging them, by instead setting up a not-for-profit scheme and not extracting a surplus, for example. Whether it is feasible for them so to act will be complicated in practice. It may be that it is actually not possible for them so to act: one can construct hypothetical examples where only for-profit schemes are possible, and it is not even possible for an investor not to seek to retain a profit. (Suppose, fancifully, that the only way to generate sufficient funds to start a microfinance institution is to get a particular set of profit maximising business people on board. They will only join if the microfinance institution is headed by someone they trust as "one of us", which means extracting a substantial profit and spending it in conspicuous fashion.)

Feasibility is looser than this, and can take into account not only what it is physically possible for people to achieve, but also, potentially, their own psychological shortfalls and 
limitations. If someone is just not the sort of person who is ever going to be willing to run a microfinance institution on a not-for-profit (or, at least, a minimal advantage) basis, it might be that it is good, all things considered, if they go ahead and wrongfully exploit the victims of injustice - even if this means compromising on justice. To be clear, taking their moral limitations into account in this way does not make their actions right or justifiable: this is not a case of an invocation of an "ought implies can" principle. If a non-exploitative path is open to them but they are disinclined to choose it because of their own moral limitations, they are still morally culpable for their actions. But it does not necessarily follow from this that it would be better if they did not act at all. A better social state of affairs might well be brought about by their choosing to act wrongly and get their hands dirty. At the very least, it should be clear that the exploitative nature of such an initiative does not mean that it is mandatory for a third party such as the state to intervene.

One final point, by way of conclusion: we have considered the duties of the lenders and of third parties such as the state in non-ideal contexts, but relatively little has been said of the perspective of the borrowers in microcredit schemes. It might be noted, however, that the conclusion reached above - that it is wrongfully exploitative to seek to take advantage of the victims of injustice-- does have one potentially significant consequence for those who enter into microcredit agreements in order to gain access to resources which they would have in a just world. The question here concerns the nature of their moral obligation to repay their debt. We would normally hold that voluntarily entering into a contractual arrangement such as a loan agreement is a paradigm case of how individuals voluntarily acquire obligations to others. The borrower has at least a prima facie duty to keep her side of the agreement and pay back the loan on the agreed terms. We would normally maintain that this was the case even in a situation where background distributive justice had not been realised. The key question here is not whether the holdings of the different parties are those which would be mandated by the 
proper account of distributive justice, but rather whether they are legitimate. Legitimacy is here employed as a threshold concept - even though the distribution is not perfectly just, the issue is whether it is sufficiently just to confer obligations on those who operate within it to uphold contracts and not disappoint reasonably made expectations. As Jules Coleman writes in relation to corrective justice and property rights:

In order for a scheme of rights to warrant protection under corrective justice... [the rights] must be sufficiently defensible in justice to warrant being sustained against individual infringements. Entitlements that fail to have this minimal property are not real rights in the sense that their infringement cannot give rise to a moral reason for acting... each of us can imagine political institutions that so unjustly distribute resources that no one could have a reason in justice for sustaining them by making repair (Coleman, 1992: 352-3).

It is at least arguable that the wrongful exploitation which characterises some microfinance initiatives is sufficient to nullify the moral obligation of the borrower to repay the loan which arises from the contractual agreement. To be sure, borrowers may still have good moral reasons to repay the loans, grounded especially in fair play to other borrowers in group liability microcredit schemes, and they will often have prudential reasons in addition. But if we hold that a given individual is a victim of injustice twice over, first by being denied her fair distributive share, and second by being wrongfully exploited, it is hard to see that she has a "reason in justice" to benefit the party that is exploiting her. There is only so much that we can reasonably ask of victims of injustice.

\section{Works Cited}

Anwander, Norbert (2005) 'Contributing and Benefiting: Two Grounds for Duties to the

Victims of Injustice', Ethics and International Affairs 19: 39-45. 
Microfinance, Rights and Global Justice

BBC News (2010) 'India’s micro-finance suicide epidemic' 16 December 2010 [online] available at http://www.bbc.co.uk/news/world-south-asia-11997571 [accessed 22 September 2014].

Beitz, Charles, (1979) Political Theory and International Relations. Princeton: Princeton University Press.

Beitz, Charles (1983) "Cosmopolitan ideals and national sentiment”, Journal of Philosophy 80, 591-600.

Beitz, Charles (1999) “Social and cosmopolitan liberalism”, International Affairs 75, 515529.

Blake, Michael, (2002) “Distributive justice, state coercion, and autonomy", Philosophy and Public Affairs 30, 257-96.

Butt, Daniel (2006) 'Nations, Overlapping Generations and Historic Injustice', American Philosophical Quarterly 43: 357-67.

Butt, Daniel (2007) 'On Benefiting from Injustice', Canadian Journal of Philosophy 37: 12952.

Butt, Daniel (2009a) Rectifying International Injustice: Principles of Compensation and Restitution between Nations. Oxford: Oxford University Press.

Butt, Daniel (2009b) “"Victors' justice'? Historic injustice and the legitimacy of international law", in Lukas H. Meyer (ed.) Legitimacy, Justice and Public International Law. Cambridge: Cambridge University Press. 
Microfinance, Rights and Global Justice

Butt, Daniel (2012), "Repairing historical wrongs and the end of empire", Social and Legal Studies 21: 227-242.

Caney, Simon (2005) Justice Beyond Borders: A Global Political Theory. Oxford: Oxford University Press.

Casal Paula, (2007) "Why sufficiency is not enough,” Ethics 117, 296-326.

CGAP, "Good Practice Guidelines for the Funders of Microfinance", available at http://www.cgap.org/publications/good-practice-guidelines-funders-microfinance [accessed 22 September 2012].

Cohen, G.A. (2000) If You're an Egalitarian, How Come You're So Rich? Cambridge, MA: Harvard University Press.

Cohen, G.A. (2008) Rescuing Justice and Equality Cambridge, MA: Harvard University Press.

Cohen, G.A. (2011) On the Currency of Egalitarian Justice, and Other Essays in Political Philosophy Princeton, NJ: Princeton University Press.

Coleman, Jules (1992) Risks and Wrongs. Cambridge: Cambridge University Press.

Fullinwider, Robert (2002) 'Preferential Hiring and Compensation', in Steven M. Cahn (ed.), The Affirmative Action Debate. New York: Routledge, 68-78.

Goodin, Robert (1985) Protecting the vulnerable. Chicago: University of Chicago Press.

Goodin, Robert (1987) ‘Exploiting a situation and exploiting a person’ in A. Reeve (ed.), Modern theories of exploitation. London: Sage, 166-200 
Microfinance, Rights and Global Justice

Goodin, Robert (1989) “The state as a moral agent”, in A. Hamlin \& P. Pettit (eds.), The Good Polity. Oxford: Blackwell.

Gosseries, Axel (2004) 'Historical Emissions and Free-riding', Ethical Perspectives 11: 3862.

Johnson, Susan and Rogaly, Ben (1997), Microfinance and Poverty Reduction. Oxford:

Oxfam.

Lippert-Rasmussen, Kasper, (2009) "Justice and Bad Luck", The Stanford Encyclopedia of Philosophy (Fall 2009 Edition), Edward N. Zalta (ed.), [online] available at http://plato.stanford.edu/archives/fall2009/entries/justice-bad-luck/ [accessed 22 September 2014].

Logar, Tea (2010), 'Exploitation as Wrongful Use: Beyond Taking Advantage of Vulnerabilities', Acta Analytica 25, 329-346.

Miller, David, (1987) "Exploitation in the market”, in Andrew Reeve (ed.), Modern Theories of Exploitation London: Sage, 149-65.

Miller, David (1995) On Nationality Oxford: Clarendon.

Miller, David (2007) National Responsibility and Global Justice. Oxford: Oxford University Press.

Moore, B., (1973) Reflections on the Causes of Human Misery, Boston: Beacon Press.

Morduch, Jonathan (1999) “The Microfinance Promise” Journal of Economic Literature 37, $1569-1614$.

Moellendorf, Darrel (2002) Cosmopolitan Justice Boulder, Colorado: Westview. 
Microfinance, Rights and Global Justice

Murphy, Liam (2000) Moral Demands in Non-Ideal Theory. Oxford: Oxford University Press, 2000.

Nagel, Thomas (2005) 'The Problem of Global Justice', Philosophy and Public Affairs 33: $113-47$.

Nozick, Robert (1974) Anarchy, State, and Utopia. New York: Basic Books.

O’Neill, Onora (2000) Bounds of Justice Cambridge: Cambridge University Press.

Patten, Alan (2005) "Should we stop thinking about poverty in terms of helping the poor?", Ethics \& International Affairs 19, 19-27.

Pogge, Thomas (1989) Realizing Rawls. Ithaca: Cornell University Press.

Pogge, Thomas (2002) World Poverty and Human Rights. Cambridge: Polity.

Pogge, Thomas (2005) "Symposium: World Poverty and Human Rights", Ethics and International Affairs 19, 1-7.

Polgreen, Lydia \& Vikas Bajaj, 'India Microcredit Faces Collapse From Defaults', New York Times, 17 November 2010 available at

http://www.nytimes.com/2010/11/18/world/asia/18micro.html 11997571 [accessed 22 September 2014].

Rawls, John (1972) A Theory of Justice Oxford: Oxford University Press.

Rawls, John (1999) The Law of Peoples. Cambridge, MA: Harvard University Press.

Sample, Ruth J. (2003) Exploitation: What it Is and Why it's Wrong. Lanham: Rowman \& Littlefield. 
Microfinance, Rights and Global Justice

Sangiovanni, Andrea (2007) "Global justice, reciprocity and the state", Philosophy and Public Affairs 35: 3-39.

Solan, David E. (2011) 'How Consumer Bankruptcy Reforms Can Help Save Microfinance in India' Oregon Review of International Law 13: 317-354

Steiner, Hillel (1987) "Exploitation: a liberal theory amended, defended and extended", in Andrew Reeve (ed.), Modern Theories of Exploitation. London: Sage, 132-48.

Tamir, Yael (1993) Liberal Nationalism. Princeton: Princeton University Press.

Tan, Kok-Chor (2007) 'Colonialism, Reparations, and Global Justice', in Jon Miller and Rahul Kumar (eds), Reparations: Interdisciplinary Inquiries. Oxford: Oxford University Press, 280-306.

Temkin, Larry (1996), Inequality. Oxford: Oxford University Press.

Waldron, Jeremy (1992) 'Superseding Historic Injustice’, Ethics 103: 4-28.

Wertheimer, Alan (1996) Exploitation. Princeton: Princeton University Press.

Wertheimer, Alan (2008) 'Exploitation', in Edward N. Zalta (ed), The Stanford Encyclopedia of Philosophy (Fall 2008 Edition) [online] available at http://plato.stanford.edu/archives/fall2008/entries/exploitation/ [accessed 22 September 2014].

Ypi, Lea., Robert Goodin, and Christian Barry (2009) 'Associative Duties, Global Justice, and the Colonies' Philosophy \& Public Affairs 37: 103-35. 